\title{
Genetic Mapping and Properties of Filamentous Mutations in Bacillus. subtilis
}

\author{
Takashi Akamatsu and Junichi Sekiguchi* \\ Department of Applied Microbiology and Technology, Kumamoto Institute of Technology, \\ Ikeda 4-22-1, Kumamoto 860, Japan and \\ Department of Applied Biology, Faculty of Textile Science and Technology, \\ Shinshu University, Tokida 3-15-1, Ueda 386, Japan
}

Received May 1, 1987

\begin{abstract}
Seven filamentous $(f i l)$ mutants were isolated from $B$. subtilis, and the mutations were mapped by means of lysed-protoplast transformation. Five of the mutations were linked to aro $D$ and the others to pyrD. rgn mutations, which lead to a decrease in autolysin(s) and the formation of filaments, were also linked to $\operatorname{aroD}$, and the mapping order was rgn-dnaE-aroD. On comparison with other reported filamentous mutations (lyt-1, lyt-2 and lyt-152), fll-1, fil-3 to -6, rgn and the above lyt mutations were determined to be in the same locus. All of the seven fil strains lacked flagella and showed decreased autolysin activity. Among them, only mutants having aroD-linked mutations showed low competency. Protease assay results indicated that rgn mutants produce a several times higher amount of the enzyme than the parent strain, and the initiation time for the production in rgn mutants was two hours earlier than in the parent strain.
\end{abstract}

Bacillus subtilis is one of the most extensively genetically and biochemically characterized gram-positive bacteria, and it exhibits peculiar features (e.g., extracellular enzyme production and sporulation) that Escherichia coli does not. ${ }^{1)}$ But, fundamental research on the cell wall and membrane of $B$. subtilis lags far behind that in the case of E. coli, ${ }^{2)}$ and also the secretion mechanism remains obscure.

Being exceptional, several pleiotropic mutations (pap, amyB and $\operatorname{sac} U^{\mathrm{h}}$ ) that lead to simultaneous increases in the production of $\alpha$-amylase, serine and metal proteases, and levansucrase are known. ${ }^{3 \sim 5)}$ The mutations, mapped in the $s a c U$ locus, lead to a lack of both competency and flagella, and a decreased amount of autolysin(s). On the other hand, rgn mutants, originally isolated to increase the regeneration of protoplasts, had some similar properties to sacU (e.g., a low autolysin amount, non-competency and a lack of flagella). ${ }^{6)}$
Grant and Simon investigated flagellaminus $(f l a)$ mutants ${ }^{7)}$ and later Fein and Rogers also investigated flagella-minus mutants which exhibit a decreased amount of autolysin(s). ${ }^{8}$ ) Recently, Pooley and Karamata ${ }^{9)}$ reported the mapping of autolysin mutations $(l y t)$, which showed that $l y t-1$ and $l y t-2$ are located in $f l a D$ $\left(219^{\circ}\right)$ and $l y t-15$ in $f a A\left(145^{\circ}\right)$. The other $f l a$ loci are $f a B\left(149^{\circ}\right)$ and $f l a C\left(315^{\circ}\right)$. We also investigated the properties and loci of $l y t$ mutants and obtained the following results: (1) a lyt mutant, Ni15, has three autolysindeficient (lyt) mutations (lyt-15, lyt-151 and lyt-152), (2) lyt-15 is linked to pyrD1 $\left(135^{\circ}\right)$, lyt-151 to his $A\left(299^{\circ}\right)$ and lyt-152 to aroD $\left(230^{\circ}\right)$, (3) these mutations lead to a lack of flagella, and (4) lyt-151 and lyt-152 mutants are filamentous whereas the lyt-15 mutant is rod-shaped (Mol. Gen. Genet., in press).

In this report, we describe the isolation of filamentous $(f i l)$ mutants and the comparison of genetic loci and biochemical properties be- 
TABLE I. Bacillus subtilis STRAINS

\begin{tabular}{|c|c|c|}
\hline Strain designation & Genotype & Reference, source or derivation \\
\hline $168 \mathrm{~S}$ & $\operatorname{str} A \operatorname{trp} C 2$ & T. Seki \\
\hline YS11 & purB6 arg-15 leuB8 & T. Seki \\
\hline AG5 & purB6 arg-15 rgn-1 leuB8 & Akamatsu and Sekiguchi (1983) \\
\hline AH6 & purB6 arg-15 rgn-2 leuB8 & Akamatsu and Sekiguchi (1983) \\
\hline $1 \mathrm{~A} 22$ & ilvA1 metB5 dnaE20 & BGSC $^{a}$ \\
\hline $1 \mathrm{~A} 483$ & metC3 lyt-1 & BGSC; FJ3 strain \\
\hline $1 \mathrm{~A} 484$ & metC3 lyt-2 & BGSC; FJ6 strain \\
\hline $1 \mathrm{~A} 504$ & $\begin{array}{l}\text { xin-15 lyt-15 thy A thyB trpC2 lyt-151 } \\
\text { lyt-152 }\end{array}$ & BGSC; Ni15 strain; $*^{b}$ \\
\hline CT11-6 & hisH2 rgn-1 & * \\
\hline AC 310 & purB tet- $I^{c}$ & * \\
\hline $\mathrm{AC} 325$ & purB rgn-1 & Tfm (AC310: CT11-6 DNA, Tc $\left.{ }^{r} \operatorname{Rgn}^{-}\right)^{d}$ \\
\hline AC 327 & purB his-1 & $*$ \\
\hline AC343 & strA met-1 glt-1 trpC2 leu-2 his-1 purA & * \\
\hline $\mathrm{AC} 408$ & pyrD his-1 & * \\
\hline AC415 & lys aroD120 asaA4 leu-2 & * \\
\hline AC416 & $\operatorname{trpC2}$ lys leu-2 & Akamatsu and Sekiguchi (1987) \\
\hline AC551 & purB his-1 fil-1 & NTG mutagenesis of AC327, $\mathrm{Fil}^{-e}$ \\
\hline AC552 & purB his-1 fil-2 & NTG mutagenesis of AC327, Fil $^{-}$ \\
\hline AC553 & purB his-1 fil-3 & NTG mutagenesis of AC327, $\mathrm{Fil}^{-}$ \\
\hline AC554 & purB his-1 fil-4 glu-1 com-1 & $\begin{array}{l}\text { NTG mutagenesis of } \mathrm{AC} 327 \\
\text { Fil }^{-} \mathrm{Glu}^{-} \mathrm{Com}^{-f}\end{array}$ \\
\hline AC555 & purB his-1 fil-5 & NTG mutagenesis of AC327, $\mathrm{Fil}^{-}$ \\
\hline AC556 & purB his-1 fil-6 & NTG mutagenesis of AC327, $\mathrm{Fil}^{-}$ \\
\hline AC557 & purB his-1 fil-7 & NTG mutagenesis of AC327, $\mathrm{Fil}^{-}$ \\
\hline AC601 & lys fil-1 leu-2 & Tfm (AC415: AC551 DNA, Aro $^{+} \mathrm{Asa}^{+} \mathrm{Fil}^{-}$) \\
\hline AC602 & purB fil-2 & Tfm (AC310: AC552 DNA, Tet $^{+}$Fil $\left.^{-}\right)$ \\
\hline AC603 & lys fil-3 leu-2 & Tfm (AC415: AC553 DNA, Aro $\left.^{+} \mathrm{Asa}^{+} \mathrm{Fil}^{-}\right)$ \\
\hline AC604 & lys fil-4 leu-2 com-1 & $\begin{array}{l}\text { Tfm (AC415: AC554 DNA, } \mathrm{Aro}^{+} \mathrm{Asa}^{+} \\
\left.\mathrm{Fil}^{-} \mathrm{Com}^{-}\right)\end{array}$ \\
\hline AC605 & lys fil-5 leu-2 & Tfm (AC415: AC555 DNA, $\left.\mathrm{Aro}^{+} \mathrm{Asa}^{+} \mathrm{Fil}^{-}\right)$ \\
\hline AC606 & lys fil-6 leu-2 & Tfm (AC415: AC556 DNA, Aro $\left.^{+} \mathrm{Asa}^{+} \mathrm{Fil}^{-}\right)$ \\
\hline AC607 & purB fil-7 & Tfm (AC310: AC557 DNA, Tet $^{+}$Fil $\left.^{-}\right)$ \\
\hline AC609 & his-1 fil-2 & Tfm (AC408: AC552 DNA, $\left.\mathrm{Ura}^{+} \mathrm{Fil}^{-}\right)$ \\
\hline AC610 & his-1 fil-7 & Tfm (AC408: AC557 DNA, $\mathrm{Ura}^{+} \mathrm{Fil}^{-}$) \\
\hline AC620 & lys rgn-2 leu-2 & Tfm (AC415: AH6 DNA, Aro $^{+}$Asa $^{+}$Rgn $\left.^{-}\right)$ \\
\hline AC621 & lys lyt-1 leu-2 & Tfm (AC415: 1A483 DNA, Aro $^{+} \mathrm{Asa}^{+} \mathrm{Lyt}^{-}$) \\
\hline AC622 & lys lyt-2 leu-2 & Tfm (AG415: 1A484 DNA, $\mathrm{Aro}^{+} \mathrm{Asa}^{+} \mathrm{Lyt}^{-}$) \\
\hline AC623 & lys lyt-152 leu-2 & Tfm (AC415: 1A504 DNA, $\mathrm{Aro}^{+} \mathrm{Asa}^{+} \mathrm{Lyt}^{-}$) \\
\hline AC703 & lys rgn-1 leu-2 & Tfm (AC415: AG5 DNA, Aro ${ }^{+} \mathrm{Asa}^{+} \mathrm{Rgn}^{-}$) \\
\hline AC705 & lys dnaE20 aroD120 asaA4 & Tfm (AC415: 1A22 DNA, $\mathrm{Leu}^{+} \mathrm{Ts}^{g}$ ) \\
\hline AC708 & lys rgn-1 dnaE20 & Tfm (AC703: AC705 DNA, $\mathrm{Leu}^{+}$Ts) \\
\hline AC790 & lys fil-4 leu-2 & Tfm (AC415: AC604 DNA, Aro $^{+} \mathrm{Asa}^{+} \mathrm{Fil}^{-}$) \\
\hline
\end{tabular}

a The Bacillus Genetic Stock Center.

$b$ Akamatsu and Sekiguchi Mol. Gen. Genet., in press.

c Tetracycline-sensitive mutation.

${ }^{d}$ Tfm, transformation; Tfm (AC310: CT11-6 DNA, $\mathrm{Tc}^{\mathrm{r}} \mathrm{Rgn}^{-}$) denotes the $\mathrm{Tc}^{\mathrm{r}} \mathrm{Rgn}^{-}$transformant of AC310 with CT11-6 DNA.

e Filamentous phenotype.

$f \mathrm{Glu}^{-}$and $\mathrm{Com}^{-}$denote the glutamic acid requirement and lower competency phenotypes, respectively. These mutations in addition to fil occurred in AC554 on NTG mutagenesis. The details of $\mathrm{Com}^{-}$are given in the text.

$g$ Temperature-sensitive. 
tween the previously reported mutations and fil ones. We also describe the mapping of $r g n$ mutations by means of protoplast fusion and lysed-protoplast transformation.

\section{MATERIALS AND METHODS}

Media. For bacterial growth, nutrient broth containing $10 \mathrm{~g}$ of beef extract (Difco), $10 \mathrm{~g}$ of bactopeptone (Difco) and $2 \mathrm{~g}$ of $\mathrm{NaCl}$ per liter $(\mathrm{pH} 7.0)$ was used. The nutrient agar medium contained $15 \mathrm{~g}$ of agar in addition to the above components.

For the isolation and /or purification of auxotrophs and transformants, Spizizen minimal medium, ${ }^{10)}$ supplemented with amino acids and/or bases, if necessary, was used.

For protoplast regeneration, HCP-1.5 medium containing $5 \mathrm{~g}$ of glucose, $5 \mathrm{~g}$ of casamino acids, $3.5 \mathrm{~g}$ of $\mathrm{K}_{2} \mathrm{HPO}_{4}$, $1.5 \mathrm{~g}$ of $\mathrm{KH}_{2} \mathrm{PO}_{4}, 0.1 \mathrm{~g}$ of L-tryptophan, $15 \mathrm{~g}$ of polyvinylpyrrolidone (K90; mean molecular weight, 700,000; Nakarai Chemicals Ltd.), $1.9 \mathrm{~g}$ of $\mathrm{MgCl}_{2}$ and $250 \mathrm{ml}$ of $1.2 \mathrm{M}$ sodium succinate $(\mathrm{pH} 7.3)$ per liter was used. HCP1.5 agar medium comprised HCP-1.5 medium supplemented with $8 \mathrm{~g}$ of agar per liter. HCP-3 medium was the same as HCP-1.5 medium except that the polyvinylpyrrolidone was increased to $30 \mathrm{~g}$ per liter. Solutions of $\mathrm{MgCl}_{2}$, sodium succinate and polyvinylpyrrolidone were autoclaved separately to prevent salt precipitation. Autoclaving a mixture of polyvinylpyrrolidone and agar prevented solidification of the medium.

Microorganisms. The strains used in this study are listed in Table I. Filamentous ( $f i l)$ mutants were obtained from Bacillus subtilis AC 327 as follows. $0.2 \mathrm{ml}$ of a culture of $B$. subtilis AC327 grown in nutrient broth $(5 \mathrm{ml})$ at $37^{\circ} \mathrm{C}$ for $14 \mathrm{hr}$ was transferred to $20 \mathrm{ml}$ of nutrient broth, followed by incubation at $37^{\circ} \mathrm{C}$ for $2 \mathrm{hr}$. The logárithmic-phase cells were collected by centrifugation and then suspended in $10 \mathrm{ml}$ of $0.1 \mathrm{~m}$ Tris-maleate buffer ( $\mathrm{pH} 6.0$ ) containing $200 \mu \mathrm{g}$ per $\mathrm{ml}$ of $N$-methyl- $N^{\prime}$-nitro- $N$-nitrosoguanidine (MNNG) in a $100-\mathrm{ml}$ flask, followed by incubation at $37^{\circ} \mathrm{C}$ for $30 \mathrm{~min}$. After centrifugation of the culture, the pellet was suspended in $1 \mathrm{ml}$ of nutrient broth, and then a $0.1-\mathrm{ml}$ portion of the suspension was transferred to $5 \mathrm{ml}$ of nutrient broth. After incubation at $37^{\circ} \mathrm{C}$ for $14 \mathrm{hr}, 0.2 \mathrm{ml}$ of the culture was further transferred to $20 \mathrm{ml}$ of nutrient broth to obtain a log-phase culture. After incubation at $37^{\circ} \mathrm{C}$ for $3 \mathrm{hr}, 10 \mathrm{ml}$ of the culture was centrifuged at $7,200 \times g$ for $10 \mathrm{~min}$. Since we knew that the filamentous mutants, lyt-1, lyt-2, rgn-1 and rgn-2, are apt to float.up within a few minutes upon centrifugation under the above conditions, the centrifuge tube was slowly spun, and then the floating cells were pipetted out, diluted in nutrient broth and plated onto nutrient agar plates. The colonies that grew overnight at $37^{\circ} \mathrm{C}$ were examined for filamentation under a light microscope. To confirm filamentation, cells grown in a liquid culture were also examined.
Protoplast formation and transformation with gently lysed protoplasts ( $L P$ transformation). Protoplasts and competent cells were prepared as described by Akamatsu and Sekiguchi ${ }^{11)}$ and Anagnostopoulos and Spizizen, ${ }^{12)}$ respectively. LP transformation was carried out as described previously. ${ }^{13)} 0.1 \mathrm{ml}$ of a protoplast suspension was added to $1 \mathrm{ml}$ of competent cells in a hypotonic buffer, followed by incubation at $37^{\circ} \mathrm{C}$ for $30 \mathrm{~min}$. Then the cells were plated on minimal agar supplemented with appropriate nutrients. Each colony was further transferred to diagnostic agar plates and unselected marker(s) were determined.

Percent cotransformation was defined as (number of cotransformants per number of total transformants) $\times 100$.

Protoplast fusion and regeneration. The protoplast fusion method used was basically the same as that of Schaeffer et al. ${ }^{14)}$ Two protoplast suspensions, from different strains, were mixed and vortexed in SMM $(0.5 \mathrm{M}$ sucrose $-0.02 \mathrm{M} \mathrm{MgCl}-0.02 \mathrm{M}$ maleate buffer, $\mathrm{pH}$ 6.5), followed by the addition of $40 \%$ polyethyleneglycol 4000 (average molecular weight, 3,000; Wako Pure Chem. Ind. Ltd.). After standing at $0^{\circ} \mathrm{C}$ for $1 \mathrm{~min}$, the protoplast suspensions were diluted with HCP-1.5 medium.

The protoplast regeneration method was described previously. ${ }^{11)}$ A $0.1-\mathrm{ml}$ portion of the diluted protoplast suspension was placed on the surface of HCP-1.5 agar medium, followed by overlaying with $4 \mathrm{ml}$ of the same medium containing agar. Colonies appearing on the regeneration agar medium were streaked on nutrient agar and then single colonies were examined for unselected markers.

Enzyme assays. The autolytic enzyme preparations and cell walls for the assays were prepared as described previously. $\left.{ }^{6}\right)$ Log-phase cells were harvested and disrupted by ultrasonication. After centrifugation, the pellet was used as the cell wall fraction containing autolysins. The initial cell-wall concentration was always 0.2 at $A_{540 \mathrm{~nm}}$ and the percent decrease in $A_{540 \mathrm{~nm}}$ at $40^{\circ} \mathrm{C}$ in TK buffer $(0.1 \mathrm{M}$ Tris(hydroxymethyl)aminomethane, $\mathrm{pH} \quad 8.0$, containing $0.1 \mathrm{M} \mathrm{KCl}$ ) was recorded.

Protease activity was determined as described previously. ${ }^{4)}$ One unit of protease activity was defined as the amount of the enzyme which solubilized $1 \mu \mathrm{g}$ equivalent of tyrosine in $1 \mathrm{~min}$.

Flagella staining, cell motility and morphology. The flagella of cells cultivated on nutrient agar at $37^{\circ} \mathrm{C}$ overnight were stained as described by Doetsch. ${ }^{15)}$ Cell motility was investigated both on nutrient agar containing $0.5 \%$ agar and under a phase-contrast microscope. Cell morphology was investigated at the logarithmic phase of growth in nutrient broth. 


\section{RESULTS AND DISCUSSION}

Filamentous mutants (e.g., lyt and rgn) tend to float up from pellets within a short time on high-speed centrifugation, and so we used this property for enrichment of filamentous mutants. Colonies grown on nutrient agar plates after plating of supernatants obtained on centrifugation were examined for filamentation. Candidates were transferred to nutrient broth and then incubated at $37^{\circ} \mathrm{C}$ until the growth reached the logarithmic phase. Filamentation of the cells was examined under a light microscope, and finally seven filamentous mutants( $f i l-1$ to fil-7) were isolated from different cultures.

\section{Mapping of the fil-1 and fil-3 to fil-6 mutations through LP transformation}

Autolysin-less mutants, e.g., lyt-1 and lyt-2, form filaments, and their genetic locus has been determined to be between lys and aro $D .{ }^{9)}$ These results prompted us to investigate the linkage of fil mutations to the aroD locus. LP transformation of AC415 with AC551, AC553, AC554, AC555 and AC556 DNAs indicated that the fil mutations were linked to aro $D$ at the frequency of $11.5 \%$ to $22.2 \%$ (Table II). As to congression, linkages of aroDleu-2 (map distance of $20^{\circ}$ ) and aroD-lys $\left(16.5^{\circ}\right.$ ) (from the linkage map in Fig. 1 of Piggot and Hoch, 1985) ${ }^{16)}$ were less than $2.8 \%$ and $5.6 \%$, respectively. On the other hand, there was no significant linkage between aroD and fil-2 or fil-7 (data not shown).

\section{Mapping of rgn mutations through protoplast} fusion and LP transformation

Previous results indicated that rgn mutants also form filaments and contain a decreased amount of autolysin(s). ${ }^{6)}$ Since protoplast fusion is a convenient method for genetic mapping, protoplasts from a standard polyauxotrophic marker strain (AC343) were fused with ones from the rgn-1 mutant (AC325). $\mathrm{Ade}^{+}$ fusants were selected on HCP-3 agar medium

TABle II. Linkage Relationships of aro D to $f l-1$, fil-3, fil-4, fil-5 AND fil-6 ON LP TRANSFORMATION

\begin{tabular}{|c|c|c|c|c|c|c|c|c|}
\hline \multirow{3}{*}{$\begin{array}{l}\text { Donor }^{a} \\
\text { (genotype) }\end{array}$} & \multirow{3}{*}{$\begin{array}{l}\text { Recipient }^{b} \\
\text { (genotype) }\end{array}$} & \multirow{3}{*}{ Selection } & & \multicolumn{5}{|c|}{ Recombinant } \\
\hline & & & \multicolumn{5}{|c|}{ Class } & \multirow[b]{2}{*}{$\begin{array}{l}\text { Total } \\
\text { No. }\end{array}$} \\
\hline & & & $\begin{array}{l}\text { Lys }^{-} \\
\mathrm{Leu}^{-} \\
\mathrm{Fil}^{+}\end{array}$ & $\begin{array}{l}\text { Lys }^{-} \\
\text {Leu }^{-} \\
\text {Fil }^{-}\end{array}$ & $\begin{array}{c}\mathrm{Lys}^{+} \\
\mathrm{Leu}^{-} \\
\mathrm{Fil}^{+}\end{array}$ & $\begin{array}{l}\mathrm{Lys}^{+} \\
\mathrm{Leu}^{-} \\
\mathrm{Fil}^{-}\end{array}$ & $\begin{array}{l}\mathrm{Lys}^{-} \\
\mathrm{Leu}^{+} \\
\mathrm{Fil}^{+}\end{array}$ & \\
\hline $\begin{array}{l}\text { AC551 } \\
\left(\begin{array}{l}\text { purB his-1 } \\
\text { fil-1 }\end{array}\right)\end{array}$ & $\begin{array}{c}\mathrm{AC} 415 \\
\left(\begin{array}{l}\text { lys aro D120 } \\
\text { asaA4 leu-2 }\end{array}\right)\end{array}$ & $\mathrm{Aro}^{+}$ & $72^{c}$ & 12 & 1 & 2 & 1 & 88 \\
\hline $\begin{array}{l}\mathrm{AC} 553 \\
\quad(\text { purB his-1 fil-3) }\end{array}$ & $\mathrm{AC} 415$ & $\mathrm{Aro}^{+}$ & 70 & 12 & 4 & 0 & 2 & 88 \\
\hline $\begin{array}{l}\mathrm{AC} 554 \\
\left(\begin{array}{l}\text { purB his-1 fl- } 4 \\
\text { glu-1 com-1 }\end{array}\right)\end{array}$ & $\mathrm{AC} 415$ & $\mathrm{Aro}^{+}$ & 52 & 14 & 2 & 2 & 2 & 72 \\
\hline $\begin{array}{l}\mathrm{AC} 555 \\
\quad(\text { purB his-1 fil-5) }\end{array}$ & $\mathrm{AC} 415$ & $\mathrm{Aro}^{+}$ & 88 & 12 & 4 & 0 & 0 & 104 \\
\hline $\begin{array}{l}\text { AC556 } \\
\text { (purB his-1 fil-6) }\end{array}$ & AC415 & $\mathrm{Aro}^{+}$ & 66 & 12 & 2 & 0 & 0 & 80 \\
\hline
\end{tabular}


and the unselected markers were identified. The distribution of unselected marker classes is shown in Table III. The order of the markers

TABle III. Distribution of Unselected Marker Classes among Ade ${ }^{+}$Recombinants Obtained on Protoplast Fusion between B. subtilis AC343 (strA met-1 glt-1 trpC2 leu-2 his-1 purA) AND AC325 (purB rgn-1) ${ }^{a}$

\begin{tabular}{cccccccc}
\hline \multicolumn{4}{c}{$\begin{array}{l}\text { Number of colonies carrying } \\
\text { indicated unselected markers }\end{array}$} & $\begin{array}{c}\text { \% Frequency } \\
\text { of Rgn }\end{array}$ \\
\cline { 1 - 5 } Met & Glt & Trp & Leu & His & Number & \\
\hline+ & + & + & + & + & 11 & $100(11 / 11)^{b}$ \\
- & + & + & + & + & 48 & $100(20 / 20)$ \\
- & - & + & + & + & 10 & $100(10 / 10)$ \\
- & - & - & + & + & 5 & $60(3 / 5)$ \\
- & - & - & - & + & 8 & $0(0 / 8)$ \\
- & - & - & - & - & 8 & $0(0 / 8)$ \\
- & - & - & + & - & 1 & \\
- & - & + & - & - & 1 & \\
- & + & - & - & + & 2 & \\
+ & + & - & + & + & 1 & \\
- & + & + & - & + & 1 & \\
- & + & + & + & - & 2 & \\
- & + & - & + & - & 1 & \\
& & & & & & &
\end{tabular}

a The double, quadruple and sextuple cross-over classes comprise lines 1 to 6,7 to 12 , and 13 , respectively.

$b$ In parentheses are the numbers of $\mathrm{Rgn}^{-}$recombinants per number of recombinants examined in each class. in the genetic map of $B$. subtilis was $\operatorname{str} A$ pur B-met-1-glt-1-trpC2-leu-2-his-1-purAstrA (Mol. Gen. Genet., in press). The ratios of double, quadruple and sextuple cross-over recombinants to the total recombinants were $91 \%, 8 \%$ and $1 \%$, respectively. Among the double cross-over recombinants, the crossover between $\operatorname{trpC} 2$ and leu-2 led to $60 \%$ $\mathrm{Rgn}^{-}$. Cross-overs before the trpC2-leu-2 region and after this region led to $100 \%$ and $0 \%$ $\mathrm{Rgn}^{-}$phenotypes, respectively. These results clearly indicated that the rgn-1 marker was located between $\operatorname{trpC} 2$ and $l e u-2$.

The rgn-1 mutation was further mapped through LP transformation (Table IV). rgn-1 linked to $\operatorname{dnaE}$ at a frequency of $29 \%$, and dnaE to aroD120 at frequencies of $36 \%$ to $39 \%$. But lys did not link to dnaE or aroD on LP transformation. The three-factor cross in Table IV also indicates the order of $r g n-1$ dnaE-aroD120. Furthermore, the rgn-2 mutation was found to be linked to the aroD locus (data not shown).

Since $l y t-1,-2$ and -152 , fil- 1 and -3 to -6 , rgn-1 and -2 are located near aroD, whether or not these mutations are in the same locus was examined. LP transformation of AC708 (lys rgn-1 dnaE20) with AC620 (rgn-2), AC621 (lyt-1), AC622 (lyt-2), AC623 (lyt-152), AC601 (fil-1), AC603 (fil-3), AC604 (fil-4), AC605 (fil5) and AC606 (fil-6) with dnaE selection

Table IV. Linkage Relationships of $r g n-1$ to aroD120 And dnaE on LP TRAnsformation

\begin{tabular}{|c|c|c|c|c|}
\hline \multirow{2}{*}{$\begin{array}{l}\text { Donor }^{a} \\
\text { (genotype) }\end{array}$} & \multirow{2}{*}{$\begin{array}{l}\text { Recipient }{ }^{b} \\
\text { (genotype) }\end{array}$} & \multirow{2}{*}{ Selection } & \multicolumn{2}{|c|}{ Recombinant } \\
\hline & & & Class & Number \\
\hline $\begin{array}{l}\text { 168S } \\
\quad(\operatorname{str} A \operatorname{trp} C 2)\end{array}$ & $\begin{array}{c}\mathrm{AC705} \\
\left(\begin{array}{l}\text { lys dnaE20 } \\
\text { aroD120 asaA4 }\end{array}\right)\end{array}$ & $\mathrm{Ts}^{+c}$ & $\begin{array}{l}\text { Aro }^{+} \mathrm{Lys}^{-} \\
\text {Aro }^{-} \mathrm{Lys}^{-}\end{array}$ & $\begin{array}{r}78 \\
122\end{array}$ \\
\hline & & $\mathrm{Aro}^{+}$ & $\begin{array}{l}\mathrm{Ts}^{+} \mathrm{Lys}^{-} \\
\mathrm{Ts}^{-} \mathrm{Lys}^{-}\end{array}$ & $\begin{array}{r}75 \\
125\end{array}$ \\
\hline $\begin{array}{l}\mathrm{AC} 703 \\
\quad(\text { lys rgn-1 leu-2) }\end{array}$ & AC705 & $\mathrm{Ts}^{+}$ & $\begin{array}{l}\text { Aro }^{+} \mathrm{Rgn}^{-} \mathrm{Lys}^{-} \\
\text {Aro }^{+} \mathrm{Rgn}^{+} \mathrm{Lys}^{-} \\
\text {Aro }^{-} \mathrm{Rgn}^{-} \mathrm{Lys}^{-} \\
\text {Aro }^{-} \mathrm{Rgn}^{+} \mathrm{Lys}^{-}\end{array}$ & $\begin{array}{l}15 \\
23 \\
16 \\
52\end{array}$ \\
\hline
\end{tabular}

a The numbers of protoplasts of $168 \mathrm{~S}$ and $\mathrm{AC} 703$ were $2.4 \times 10^{4}$ and $2.5 \times 10^{4}$, respectively.

$b \quad$ The number of recipient cells was $7.5 \times 10^{7}$.

$c$ Temperature-independence, phenotype of $d n a E 20^{+}$. 
yielded ratios of 0/96 (number of respectively).

$\mathrm{Rgn}^{+}$transformants per number of total transformants), $0 / 103,0 / 111,0 / 1859,2 / 1738$, $1 / 2101,0 / 78,0 / 97$ and $0 / 109$, respectively.

Mapping of the fil-2 and fil-7 mutations through LP transformation

These results indicate that these mutations are in the same flaD locus (the lyt-1 and -2 loci were recently designated as $f a D 1$ and $f a D 2$,

LP transformation of AC408 with the AC602 and AC607 protoplast lysates indicated a $25 \%$ linkage between fil-2 and pyrD

Table V. Linkage Relationships of pyrd to fil-2 and fil-7 on LP Transformation

\begin{tabular}{|c|c|c|c|c|}
\hline \multirow{2}{*}{$\begin{array}{l}\text { Donor }^{a} \\
\text { (genotype) }\end{array}$} & \multirow{2}{*}{$\begin{array}{l}\text { Recipient }^{b} \\
\text { (genotype) }\end{array}$} & \multirow{2}{*}{ Selection } & \multicolumn{2}{|c|}{ Recombinant } \\
\hline & & & Class & Number \\
\hline $\begin{array}{l}\mathrm{AC602} \\
\qquad(\text { purB fil-2) }\end{array}$ & $\begin{array}{c}\mathrm{AC} 408 \\
(\text { pyrD his-1) }\end{array}$ & $\mathrm{Ura}^{+c}$ & $\begin{array}{l}\mathrm{Fil}^{-} \mathrm{His}^{-} \\
\mathrm{Fil}^{+} \mathrm{His}^{-} \\
\mathrm{Fil}^{-} \mathrm{His}^{+} \\
\mathrm{Fil}^{+} \mathrm{His}^{+}\end{array}$ & $\begin{array}{r}23 \\
67 \\
0 \\
3\end{array}$ \\
\hline $\begin{array}{l}\text { AC607 } \\
\qquad(\text { purB fil-7) }\end{array}$ & AC408 & $\mathrm{Ura}^{+}$ & $\begin{array}{l}\mathrm{Fil}^{-} \mathrm{His}^{-} \\
\mathrm{Fil}^{+} \mathrm{His}^{-} \\
\mathrm{Fil}^{-} \mathrm{His}^{+} \\
\mathrm{Fil}^{+} \mathrm{His}^{+}\end{array}$ & $\begin{array}{r}15 \\
39 \\
0 \\
0\end{array}$ \\
\hline
\end{tabular}

a The numbers of protoplasts of AC602 and AC607 used as donor DNAs were $5.0 \times 10^{3}$ and $3.0 \times 10^{3}$, respectively.

b The number of recipient cells was $5.0 \times 10^{7}$.

c The numbers of Ura ${ }^{+}$transformants were 513 and 287 on transformation of AC408 with the AC602 and AC607 lysates, respectively.

TABle VI. COMPETENCY OF THE rgn, lyt AND fil STRAins ${ }^{a}$

\begin{tabular}{llcc}
\hline Recipient $^{b}$ & \multicolumn{1}{c}{ Genotype } & No. of transformants & RTF $^{d}$ \\
\hline AG5 & purB arg-15 rgn-1 leuB8 & $1.7 \times 10^{4}$ & $4.9 \%$ \\
AH6 & purB6 arg-15 rgn-2 leuB8 & $1.2 \times 10^{3}$ & $0.34 \%$ \\
AC621 & lys lyt-1 leu-2 & $1.7 \times 10^{3}$ & $0.49 \%$ \\
AC622 & lys lyt-2 leu-2 & $4.7 \times 10^{3}$ & $1.3 \%$ \\
AC623 & lys lyt-152 leu-2 & $1.9 \times 10^{3}$ & $0.54 \%$ \\
AC601 & lys fil-1 leu-2 & $9.2 \times 10^{3}$ & $2.6 \%$ \\
AC603 & lys fil-3 leu-2 & $1.1 \times 10^{3}$ & $0.31 \%$ \\
AC604 & lys fil-4 leu-2 com-1 & $<1$ & $<0.0003 \%$ \\
AC790 & lys fil-4 leu-2 & $2.3 \times 10^{2}$ & $0.07 \%$ \\
AC605 & lys fil-5 leu-2 & $6.6 \times 10^{3}$ & $1.9 \%$ \\
AC606 & lys fil-6 leu-2 & $4.5 \times 10^{3}$ & $1.3 \%$ \\
AC416 & trpC2 lys leu-2 & $3.5 \times 10^{5}$ & $100 \%$ \\
\hline
\end{tabular}

${ }^{a} \quad$ LP transformation was carried out with B. subtilis $168 \mathrm{~S}$ protoplast lysates. The number of protoplasts was $1.0 \times 10^{7}$.

${ }^{b}$ The same amounts (at $A_{660 \mathrm{~nm}}$ ) of recipient cells were used for the transformation experiments, but the number of colony-forming units (CFU) was $1.0 \times 10^{7}$ except for the case of AC416 $\left(1.0 \times 10^{8}\right)$. Because the autolysindeficient mutants are chain-forming (filamentous) mutants (average of 10 cell units per chain after incubation in the competent medium ${ }^{12}$ ). Since the transformation frequency of the "wild-type" strain with saturated DNA amounts was as low as $0.5 \%$, it is considered that the numbers of transformants of the autolysin-deficient mutants were not affected by the chain formation.

c The number of $\mathrm{Leu}^{+}$transformants.

d Relative transformation frequency. 
and a $28 \%$ linkage between fil-7 and pyrD, respectively (Table $\mathrm{V}$ ). Congression estimated from the linkage between pyrD and his-l was less than $3 \%$. Previous results indicated that linkage values of $32 \%$ and $16 \%$ on LP transformation correspond to ones of $76 \%$ and $55 \%$ on phage PBS1 transduction, respectively. Since two flagella-minus mutations ( $f a A$ and $f l a B)$ are located near $p y r D$, and the linkage values on PBS1 transduction were $69 \%$ and $46 \%$, respectively, ${ }^{9}$ ) the fil-2 and fil-7 mutations may correspond to the flaA locus. Alternatively, the results may suggest a gene cluster of flagella mutations near the pyrD locus.

\section{Properties of the fil, rgn and lyt mutations}

It is known that some autolysin-minus mutants (i.e., amyB and $r g n$ ) lead to a decrease in competency. Among the fil mutants, the fil-2 and fil-7 ones retained normal competency (data not shown). But the fil-1 and fil-3 to -6 mutations in addition to the lyt-1, lyt-2 and lyt152 ones led to a decrease in competency (Table VI). The ratio of the decrease ranged from $0.07 \%$ to $4.9 \%$, except for in the case of the AC604 strain. Since the competency of AC604 was extremely low, it was considered that another mutation which affects competency had occurred during the NTG treatment.

When strain AC415 (lys aroD120 asaA4 leu2) was transformed with DNA from AC604 (lys fil-4 leu-2 com-1) and $\mathrm{Fil}^{-} \mathrm{Aro}^{+} \mathrm{Asa}^{+}$ transformants were selected, all of the six transformants (e.g., AC790) examined showed similar competency levels to the other flaD mutants. Furthermore, when the recipient was changed to AC327 (purB his-1) and the same
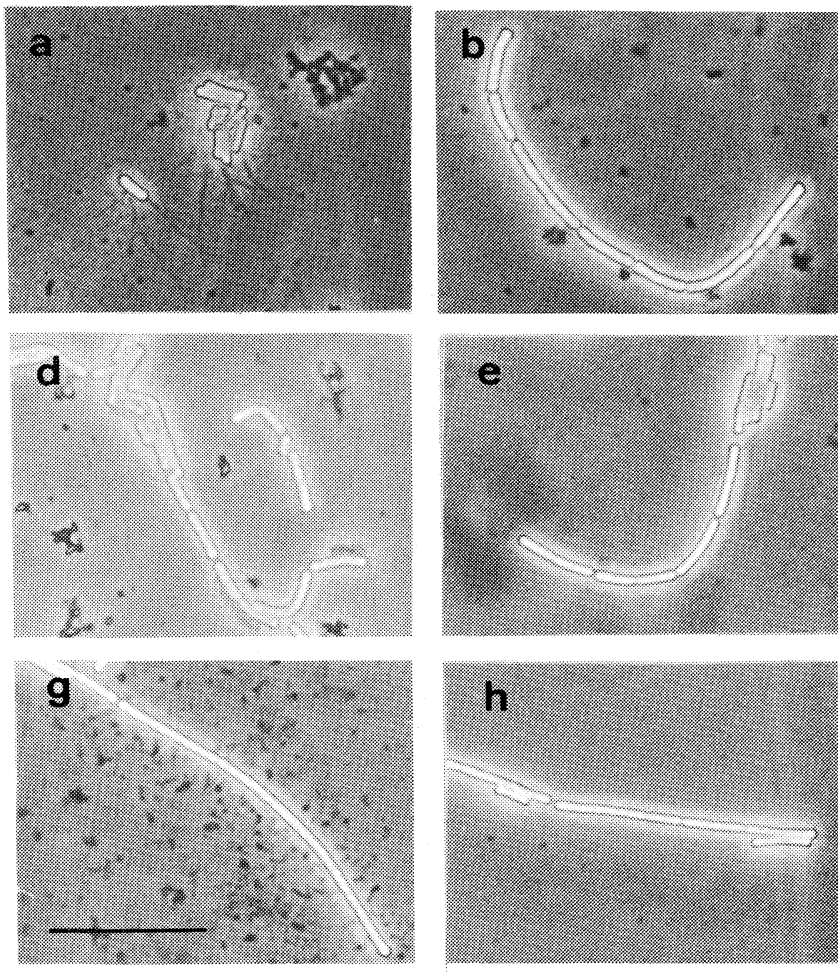
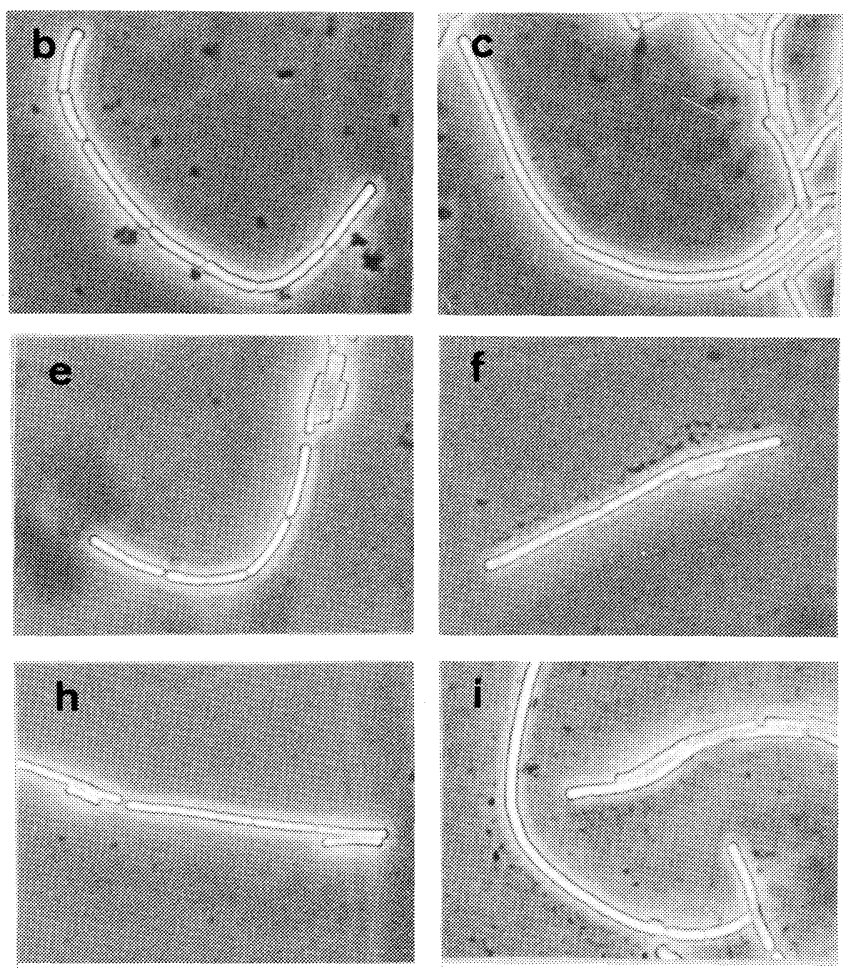

FIG. 1. Phase Contrast Illuminated Photomicrography of the Parent, and fil and rgn Mutants after Flagella Staining.

Cells grown on the nutrient agar medium for $14 \mathrm{hr}$ at $30^{\circ} \mathrm{C}$ were subjected to flagella staining as described under Materials AND Methods. Key: a, parent (AC327); b, fil-1 (AC601); c, fil-2 (AC609); d, fil-3 (AC603); e, fil-4 (AC604); f, fil-5 (AC605); g, fil-6 (AC606); h, fil-7 (AC610), i, rgn-1 (AG5). The bar represents $10 \mu \mathrm{m}$. 
transformation experiment was carried out, nine out of ten $\mathrm{His}^{+} \mathrm{Fil}^{-}$transformants retained competency at the $f l a D$ level, but one transformant exhibited extremely low competency (data not shown). These results suggest that both the fil-4 mutation and a mu-

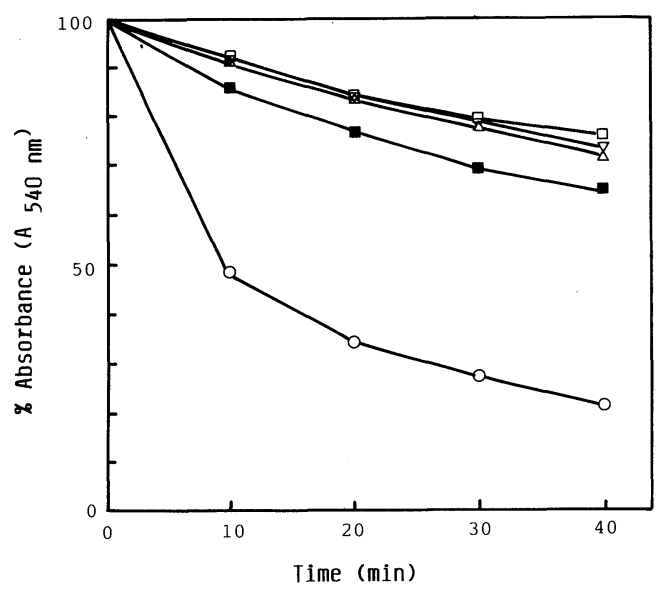

FIG. 2. Endogenous Autolytic Activities of the Parent and fil Mutants.

Symbols: $\bigcirc$, parent (AC327); $\square$, fil-3 (AC603); $\triangle$, fil-6 (AC606); $\nabla$, fil-2 (AC609); $\mathbf{\square}$, fil-7 (AC610).

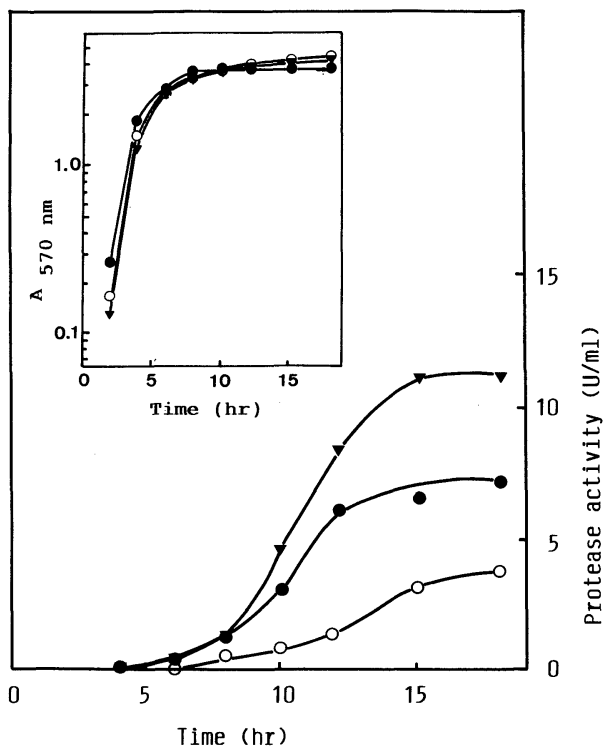

FIG. 3. Time Courses of Cell Growth and Protease Production by the rgn Mutants.

Symbols: $\bigcirc$, parent (YS11);,$r g n-1$ (AG-5); $\boldsymbol{\nabla}, r g n-2$ (AH-6). tation (designated as com- 1 ) affecting competency are present in the AC604 strain, and the fil-4 and com-1 mutations are not closely linked. Genetic mapping and investigation of the properties of the com- 1 mutation are now in progress.

Flagella staining of the fil mutants in addition to the rgn one was carried out. Figure 1 shows that all of the fil and rgn- 1 mutants lacked flagella. The lack of motility of the mutant cells prepared from logarithmic-phase cultures supported the above result.

Fein reported that autolysin deficiency leads to a loss of flagella. ${ }^{17)}$ Thus, autolysin activities were measured for the fil-2, fil-3, fil-6, and fl-7 mutants and a control strain, AC327. All of the fil mutants showed decreases in autolysin activity, ranging from $13 \%$ to $25 \%$ (Fig. 2).

Another interesting property among pleiotropic phenomena is extracellular enzyme productivity. When the $\alpha$-amylase and protease amounts in rgn mutants were measured, the protease production by rgn-1 and rgn-2 mutants was found to be 2.0 and 3.0 times higher than that by YS11, respectively (Fig. 3). But $\alpha$ amylase production by both mutants was not significantly different (unpublished results). Moreover, the time of initiation of protease production in the rgn mutants was two hours earlier than that in YS11.

A pleiotropic mutation, $s a c Q^{\mathrm{h}}$, which leads to higher production of extracellular enzymes and a decrease in competency did not cause a loss of flagella. ${ }^{18)}$ On the contrary, the hyperextracellular enzyme producing $\operatorname{sac} U^{\mathrm{h}}(a m y B$ and pap) mutation caused a decrease in competency and a lack of flagella. ${ }^{18)}$ Yang et al. reported that the $\operatorname{sac} Q$ gene product is a small 46-amino acid polypeptide and that the $\operatorname{sac} Q^{\mathrm{h}}$ mutation leads to increased expression of this polypeptide. ${ }^{19)}$ Aubert et al. reported that the sac $U$ gene product is a 46-kilodalton protein and that the $\operatorname{sac} U^{\text {h }}$ mutation leads to an increase in this protein in the membrane fraction. ${ }^{20)}$ But Aymerich et al. ${ }^{21)}$ and Shimotsu and Henner ${ }^{22)}$ reported that the $\operatorname{sac} U^{\mathrm{h}}$ mutation enhances the transcription of $\operatorname{sac} B$ (the struc- 
tural gene for an extracellular enzyme, levansucrase) and does not have an effect at secretion level. At present there is no explanation as to how the pleiotropic effect occurs.

On the basis of the results of this study, we could classify the autolysin- and/or flagelladeficient mutations into six groups as follows: (1) lyt-1, lyt-2, lyt-152, fil-1, fil-3 to fil-6, rgn-1 and rgn-2 mutations in the $f l a D\left(219^{\circ}\right)$ locus [phenotypes: flagella- and autolysin-deficient, competent-minus and filamentous]; (2) lyt-15 in flaA $\left(145^{\circ}\right)$ [phenotypes: flagella- and autolysin-deficient, and rod-shaped]; (3) fl-2 and fil-7 linked to pyrD $\left(135^{\circ}\right)$ [phenotypes: flagella- and autolysin-deficient, normal competent and filamentous]; (4) $\mathrm{flaB}\left(149^{\circ}\right)$ [phenotype: flagella-deficient; other properties are unknown]; (5) $f l a C\left(315^{\circ}\right)$ [phenotype: flagelladeficient; other properties are unknown]; and (6) lyt-151 linked to his $A\left(299^{\circ}\right)$ [flagella- and autolysin-deficient, and filamentous].

The filamentous mutations will not only be useful for elucidation of the fundamental mechanism as to cell morphology and cell envelope architecture, but also for a better understanding of the pleiotropic effects caused by the $\operatorname{sac} Q^{\mathrm{h}}$ and $\operatorname{sac} U^{\mathrm{h}}$ mutations.

Acknowledgment. This work was supported in part by a Grant-in-Aid for Scientific Research from the Ministry of Education, Science and Culture of Japan.

\section{REFERENCES}

1) P. S. Lovett, "Genetics and Breeding of Industrial Microorganisms," ed. by C. Ball, CRC Press Inc., Boca Raton, Florida, 1984, pp. $43 \sim 62$.

2) P. S. F. Mézes and J. O. Lampen, "The Molecular Biology of the Bacilli," Vol. II, ed. by D.A. Dubnau, Academic Press Inc., New York, 1985, pp. 151 183.
3) D. Ayusawa, Y. Yoneda, K. Yamane and B. Maruo, J. Bacteriol., 124, 459 (1975).

4) J. Sekiguchi, N. Takada and H. Okada, J. Bacteriol., 121, 688 (1975).

5) M. Steinmetz, F. Kunst and R. Dedonder, Mol. Gen. Genet., 148, 281 (1976).

6) T. Akamatsu and J. Sekiguchi, FEMS Microbiol. Lett., 20, 425 (1983).

7) G. F. Grant and M. I. Simon, J. Bacteriol., 99, 116 (1969).

8) J. E. Fein and H. J. Rogers, J. Bacteriol., 127, 1427 (1976).

9) H. M. Pooley and D. Karamata, J. Bacteriol., 160, 1123 (1984).

10) J. Spizizen, Proc. Natl. Acad. Sci. U.S.A., 44, 1072 (1958).

11) T. Akamatsu and J. Sekiguchi, Agric. Biol. Chem., 48, 651 (1984).

12) C. Anagnostopoulos and J. Spizizen, J. Bacteriol., 81, 741 (1961).

13) T. Akamatsu and J. Sekiguchi, Arch. Microbiol., 146, 353 (1987).

14) P. Schaeffer, B. Cami and R. D. Hotchkiss, Proc. Natl. Acad. Sci. U.S.A., 73, 2151 (1976).

15) R. N. Doetsch, "Manual of Methods for General Bacteriology," ed. by P. Gerhardt, R. G. E. Murray, R. N. Costilow, E. W. Nester, W. A. Wood, N. R. Krieg and G. B. Phillips, American Society for Microbiology, Washington, D. C., 1981, pp.'21 33.

16) P. J. Piggot and J. A. Hoch, Microbiol. Rev., 49, 158 (1985).

17) J. E. Fein, J. Bacteriol., 137, 933 (1979).

18) J. -A. Lepesant, F. Kunst, M. Pascal, K. Kejzlarov́aLepesant, M. Steinmetz and R. Dedonder, "Microbiology-1976," ed. by D. Schlessinger, American Society for Microbiology, Washington, D. C., 1976 , pp. $58 \sim 69$.

19) M. Yang, E. Ferrari, E. Chen and D. J. Henner, J. Bacteriol., 166, 113 (1986).

20) E. Aubert, A. Klier and G. Rapoport, J. Bacteriol., 161, 1182 (1985).

21) S. Aymerich, G. Gonzy-Tréboul and M. Steinmetz, J. Bacteriol., 166, 993 (1986).

22) H. Shimotsu and D. J. Henner, J. Bacteriol., 168, 380 (1986). 